\title{
STUDENTS’ READING AND LISTENING COMPREHENSION BASED ON THEIR LEARNING STYLES
}

\author{
Titing Magfirah \\ Widya Mandala Catholic University Surabaya, Indonesia \\ ti2n_magfirah@yahoo.com
}

First draft received: 30 Aug 2017 Accepted: 19 Dec 2017 Final proof received: 20 Feb 2018

\begin{abstract}
This research aims to know whether there is a significant difference between reading and listening comprehension scores based on their learning styles; visual and auditory, of the 8th-grade students of SMPN 4 Pallangga Gowa in academic year 2016-2017. This study used quantitative method and causal-comparative design. The instruments of this study included learning style questionnaire, reading comprehension test, and listening comprehension test. Further, it used independent sample $t$-test to analyze the data from learning styles questionnaire, and reading and listening comprehension scores. Findings of the result reveal that there was no significant difference between students' reading and listening comprehension scores based on two groups' learning styles: visual and auditory. The result shows that sig. values of reading comprehension based on two learning styles, visual and auditory, were 0.592 and 0.594 , respectively, which were greater than $p$-value (0.05). Similarly, the sig. values of two learning style groups in listening comprehension performance were the same, namely 0.954 . It means that both sig. values were greater than $p$-value (0.954>0.05). Hence, it can be concluded that $\mathrm{H}_{0}$ was accepted and $\mathrm{Ha}$ was rejected. Clearly, from the result, it can be said that learning style is not the only one factor affecting students' reading and listening comprehension scores.
\end{abstract}

Keywords: Learning Styles; Visual; Auditory; Reading Comprehension; Listening Comprehension

To cite this paper (in APA style):

Magfirah, T. (2018). Students' reading and listening comprehension based on their learning styles. International Journal of Education, 10(2), 107-113. doi: http://dx.doi.org/

\section{INTRODUCTION}

Reading and listening plays an important role in language teaching. Those skills cannot be separated in English acquisition. In order to be able to speak and write in English, a student should listen and read a lot beforehand. However, acquiring reading and listening skills is not easy for students since it deals with comprehension as the major goal of reading and listening for English students. Reading is about understanding written text (Pang, Muaka, Bernhardt, \& Kamil, 2003), it means that readers' ability to understand the author's message is influenced by their background knowledge of the topic given in the text (Burnes \& Page, $1985)$. That is why reading is not simply reading. As stated by Saadi (2012), many students encounter difficulties in reading because they get difficulties in comprehending reading materials. He found that teachers probably do not use an appropriate strategy in teaching English, especially reading. Then, students sometimes have less motivation and interests if the teacher uses the method of teaching which is not suitable for them, while they are supposed to master reading skill because they will find a lot of reading materials in English subject.

Compared to reading, listening is also an essential skill which develops faster than speaking and often affects the development of reading and writing abilities in learning a new language. Listening is defined as a "receptive skill" where people get the idea according to what they heard (Harmer, 2001 ). In order to comprehend spoken message, listeners may need to integrate information from a range of sources: phonetic, phonological, lexical, syntactic, semantic and pragmatic (Osada, 2004). Thus, listening is also not an easy skill to be acquired because it requires listeners to make meaning from the oral input by drawing upon their background knowledge of the world and of the second language and produce information in their long-term memory and make their own interpretations of the spoken passages. For many students, listening is a difficult skill to improve because they have to pay much attention, concentration, and sometimes they feel asleep 
(Bingol, Celik, Mart, and Yilzid, 2014). It also needs a quiet situation because when there are a lot of noises, listening in English will be hard to do.

However, acquiring both reading and listening skills is not easy for students. In this case, reading and listening problems are considered as a general problem which has motivated the writer to explore the phenomenon. Regarding this phenomenon, Gilakjani (2012) stated that one of the dominant objectives in foreign language learning settings is to raise awareness about students' personal differences and their potential effects on the learning process and subsequently on learning outcomes. In other words, personal differences brought by the students into classroom could make different learning outcomes. This is also emphasized by Ellis (1985) who argued that language learners vary on a number of dimensions: personality, learning style, motivation, aptitude and also age. These dimensions are assumed to be significant contributors that determine the success or failure in acquiring English language. One of these dimensions is learning style. Learning style refers to an individual's habitual and preferred way of absorbing, processing and retaining new information and skills (Wang, 2007). Thus, each learning style has its own strengths and weaknesses so that a person who sticks to one style is never going to be an ideal learner (Moradkhan \& Mirtaheri, 2011). Considering that learning style is the particular way in which a learner tries to learn something or the way a person prefers to learn (Richard \& Platt, 1992), the learner will enjoy and feel comfortable in absorbing the information with her or his own way. Thus, learning style is not really concerned with what the learners learn, but rather how they prefer to learn the materials. Furthermore, each person has his or her own best way to learn, governing how they prefer to receive and process the knowledge. Some learners may rely on visual image or presentation (visual), others prefer listening to the music while learning or learning better through their hearing (auditory), and others may respond better to hands-on activities (kinesthetic) (Barbe \& Milone, 1981).

Learning styles are found to affect students' learning behaviors. Bhatti and Bart (2013) conducted a study to explore the influence of learning styles on scholastic achievement levels. The major findings of the study are that the dominant learning style was Assimilator and that learning style and gender influenced academic achievement. Students who have different learning style preferences would behave differently in the way they perceive, interact with, and respond to the learning environment. Since the learners differ in their preferences of certain learning styles, it will be important for an educator to know the variations of students on the features of their learning styles because the information about students' learning style preference can help the teachers or lecturers become aware of the students' differences brought to the classroom (Wang, 2007). In fact, there are many teachers who do not pay attention to learning styles of their students. Moreover, many students also do not pay attention to their own learning style, whereas knowing it can help them to learn language easily.
Learning style seems to play a major role in academic achievement as well as in reading and listening comprehension skill (Braio, 1995; Purnomo, 2009; Saadi, 2012; Tanta, 2010). It is also proved by a research that was conducted by Rizky (2013). She conducted a causal comparative study to find out whether there is a significant difference in students' English achievement based on their visual, auditory, and kinesthetic learning styles at the second grade of SMP Islam Harapan lbu. The result showed that there was a significant difference among students' English achievement. Further, Gilakjani (2012) conducted a study to analyze the learning styles of Iranian EFL university students. The purpose of this study is to increase faculty awareness and understanding of the effect of learning styles on the teaching process. The finding showed that Iranian EFL university students' preferred visual learning style, and students with this type of learning style had the greatest academic achievement in their educational major.

Accordingly, reading and listening comprehension can be seen as students' achievement related to English acquisition. One of the factors affecting language acquisition is learning styles. Learning styles relates to reading and listening achievement because the ways students prefer to learn determine their comprehension. They feel comfortable in absorbing, acquiring, perceiving, and processing the information in their own way. Those factors make learning style related to reading and listening comprehension. Despite having a combination of learning styles, they usually have a dominant learning style or their own preference style. As a result, a comparison of learning styles, visual and auditory, needs to be investigated. It is considered and believed that if every student has different preferred ways of absorbing information or knowledge, it means that they have different achievements.

Based on reading and listening problems amongst English students, learning style, especially visual, is assumed to have influence on good achievements in reading comprehension; the same is true for the influence of auditory learning style on listening comprehension skill (Barbe \& Milone, 1981). This is also supported by Gilakjani (2012), who noted that visual learners learn by seeing and visualizing and they prefer for information to be displayed in writing, such as lists of ideas. The auditory learners tend to be natural listeners and they prefer to have things explained to them verbally rather than to read written information, and they learn by listening and verbalizing. That is why, the current research focuses only on two learning styles; visual and auditory, considering that these two learning styles are the most frequently used in reading and listening activities. Departing from this, it is important to examine whether students' learning styles, visual and auditory, affect their reading and listening comprehension. In other words, it aims to find the difference of students' reading and listening comprehension scores based on the students' learning styles. In this case, kinesthetic learning style is omitted in order to more clearly observe the difference between reading and listening comprehension based on visual 
and auditory learning styles without interference from another learning style. Nevertheless, to determine the students' learning style, this research used learning style questionnaires based on the three characteristics of learning styles: visual, auditory, and kinesthetic learning styles.

The following are the formulated questions of this research: (1) Is there any difference in students' reading comprehension based on their learning styles: visual and auditory? (2) Is there any difference in students' listening comprehension based on their styles: visual and auditory?

\section{METHODS}

This study is a quantitative method, using a causal comparative research with a posttest-only design. The basic causal-comparative is retrospective causalcomparative research, starting with effects and investigating causes. Causal-comparative is sometimes called ex-post facto, which comes from Latin for "after the fact" because both the effect and the alleged cause have already occurred and must be studied in retrospect (Ary, Jacobs, \& Razavieh, 2010). Then, Mueller (1992) also stated that causal comparative study is comparing between levels of the predictor and the criterion variable. In causal-comparative research, the predictor cannot be manipulated (Mueller, 1992).

The research used posttest-only design, involving two groups of learning styles: visual and auditory. The two groups were given reading and listening comprehension test. Further, independent sample $t$-test test was used to measure the significant differences in reading and listening comprehension between visual learning style and auditory learning style. The $t$-test is used to determine whether a pre-determined level of risk of being wrong if the null hypothesis is rejected.

Furthermore, the variables in this research were learning styles, reading comprehension, and listening comprehension. The criterion variable was the students' reading comprehension and listening comprehension performance measured through the participants' scores in reading and listening comprehension test. Meanwhile, the predictor variable was the students' learning styles. This study is only focused on visual and auditory learning styles.

The population of this research was the eighth grade of students at SMPN 4 Pallangga Gowa. English is studied as one of the school subjects, and the school instructions are delivered in Bahasa Indonesia as their mother tongue. The sample was taken by using accessible sampling, which means only the eighth grade was allowed to be tested by the principal, so the writer took the eighth-grade students from class VIII.1, VIII.2, VIII.3, VIII.4, and VIII.5 which consisted of 150 students. Each class consisted of 25-30 students. In this case, the writer took the students from class VIII.1 which had been given a try-out of listening and reading comprehension test. The purpose of implementing the try-out was to check the level of difficulty, discriminating power, and reliability of test items. Then, the writer took class VIII.2, VIII.3, VIII.4, and VIII.5 as the sample of this research, which consisted of 123 students. These classes were mixed students, meaning that in every class there were students who were good at English and there were those who were poor at it. However, there were 24 students who were absent during the test, so the total sample was only 99 students.

Next, there were three instruments of the research used in collecting the data, they were: learning style questionnaire, reading comprehension test, and listening comprehension test. The questionnaire was adopted from Reid in Gilakjani (2012); it consisted of 15 items, and there were 5 items for each kind of learning styles. The students gave their responses on the basis of a five-point Likert scale. The students' answers were scored based on Likert scale as follows: strongly agree (5), agree (4), uncertain (3), disagree (2), and strongly disagree (1). Next, the reading comprehension test consisted of reading texts taken from many sources where some of the questions were developed and adjusted to the eighth-grade level. The test was in multiple choice questions, which consisted of 30 items with four options: A, B, C, and D. Similarly, listening comprehension test consisted of 30 items of multiple choice questions, followed by four options, A, B, C and D. The listening test consisted of some short conversations taken from www.esl-lab.com. Both reading and listening comprehension tests were developed based on the Barret taxonomy of comprehension.

For the data analysis, the writer classified the categorization of learning style from the questionnaire. Then, the writer only chose the students who had major visual and auditory learning styles. Next, the writer analyzed the scores of reading and listening comprehension tests, especially for students who had visual and auditory learning styles, in this case, kinesthetic, minor or negligible learning styles were eliminated. Then, the writer created a list of students who had visual and auditory learning styles followed by their scores in reading and listening comprehension tests. To find the difference of students' reading and listening comprehension between visual and auditory learning styles, independent sample $t$-test test (two sample posttest-only design) was conducted by using the following formula;

$$
t=\frac{\bar{X}_{1}-\bar{X}_{2}}{\sqrt{\frac{s_{p}^{2}}{n_{1}}+\frac{s_{p}^{2}}{n_{2}}}}, \quad s_{p}^{2}=\frac{\left(n_{1}-1\right) s_{1}^{2}+\left(n_{2}-1\right) s_{2}^{2}}{n_{1}+n_{2}-2}
$$

(Trijono, 2015)

The formula can be explained as follows: $\bar{X}_{1}$ refers to mean of group 1 (Visual LS); $\bar{X}_{2}$ refers to mean of group 2 (Audio LS); Sp stands for pooled variance; $n_{1}$ stands for number of cases in group $1 ; n_{2}$ refers to number of cases in group 2; and s means standard deviation.

To ensure the significant difference in the sample data, the level of significance was set within the range of .01 or .05 . If the value exceeds .01 to .05 , it means no 
significant differences (Mueller, 1992). In other words, Ho (Null hypothesis) is rejected and $\mathrm{Ha}$ (Alternative hypothesis) is accepted if the $p$-value found is less than 0.05 .

\section{RESULTS AND DISCUSSION}

In order to answer the questions of the research, the writer analyzed the data of the eighth-grade students of SMPN 4 Pallangga Gowa in academic year 2016/2017. The data were taken from the students who had visual and auditory learning styles. Among 99 students who had been given questionnaire, the result revealed that there were 25 visual learners and 26 auditory learners. It means that there were 48 students eliminated, including kinesthetic (25) and minor kinesthetic (5), minor visual (10), minor auditory (7) and negligible learning style (1). Then, to find the significant difference in students' reading and listening comprehension based on their learning styles, visual and auditory, those students who had visual and auditory learning styles were analyzed based on their scores in reading and listening comprehension test using statistical computation of independent sample $t$-test. The writer used SPSS software to compute the data.

Before the computation of independent sample $t$-test, it requires a test to know whether criterion variables (reading and listening test comprehension) were normally distributed within each group. To analyze the normality test, the writer used Shapiro-Wilk test with $a=$ 0.05. Shapiro-Wilk test was used because the sample of the study was > 50 and had two group samples. The result reveals that the data were categorized as normally distributed because the value of significant was higher than 0.05 . The significant value of both groups was 0.95 and 0.138, Sig. $=0.095$ and $0.138>0.05$; hence, it can be concluded that all the data were normally distributed.

Besides, homogeneity test was also carried out. The test was conducted to recognize that the variances of data were homogenous or not. Homogenous means the data have the same characteristics. To analyze the homogeneity, this study used Levene's statistic technique. The result of homogeneity reveals that the data were homogenous. The data are homogenous if the significance value is greater than the alpha value (0.05). Therefore, it can be stated that the data were homogenous since the sig. value obtained was 0.134 for visual LS and sig. 0.227 for auditory LS, which clearly shows that was higher than 0.05 .

After knowing that the data were normally distributed and homogenous, another step of this study was continuing to conduct the hypothesis. Hypothesis testing is important to be conducted for the study to prove whether the previous assumption is right or not. It was conducted to know the significant differences between reading and listening comprehension scores based on two groups of learning styles: visual and auditory.

Further, to find the significant difference between reading and listening comprehension based on two learning styles, visual and auditory, independent sample $t$-test was conducted. Levene's test for equality of variances was used to know whether the null hypothesis $(\mathrm{Ho})$ is rejected or alternative hypothesis $(\mathrm{Ha})$ is accepted. In other words, to know whether there is a significant difference or not in the variances between the groups (visual and auditory learning styles).

Table 1 shows data computation of reading comprehension score based on visual and auditory leaners. The table shows that the reading score were higher for visual learning style $(M=58.8, S D=18.1)$ than for auditory learning style $(M=56.3, S D=14.7)$. However, based on the output on table $2 t(49)=0.538$, $p=0.593$, thus $p>.005$, meaning there was no significant difference between visual and auditory LSs in reading comprehension. The sig. value of reading comprehension score for both learning style groups (visual and auditory) were 0.592 and 0.594 , respectively. Then, in accordance with the basis of decision making in independent sample $t$-test, it can be concluded that $\mathrm{Ha}$ was rejected and $\mathrm{HO}$ was accepted. It means that there was no difference between the average reading comprehension score of students who have visual learning style and auditory learning style.

Table 1. Group statistics of visual and auditory learning styles in reading comprehension score

\begin{tabular}{cccccc}
\hline Group & N & Mean & $\begin{array}{c}\text { Std. } \\
\text { Deviation }\end{array}$ & $\begin{array}{c}\text { Std. } \\
\text { Error Mean }\end{array}$ \\
\hline \multirow{2}{*}{ Score } & $\begin{array}{c}\text { Visual } \\
\text { LS Group }\end{array}$ & 25 & 58.8000 & 18.17507 & 3.63501 \\
\cline { 2 - 5 } & $\begin{array}{c}\text { Auditory } \\
\text { LS Group }\end{array}$ & 26 & 56.3077 & 14.70991 & 2.88485 \\
\hline
\end{tabular}

Table 2. Independent samples t-test reading comprehension score of visual and auditory learning style

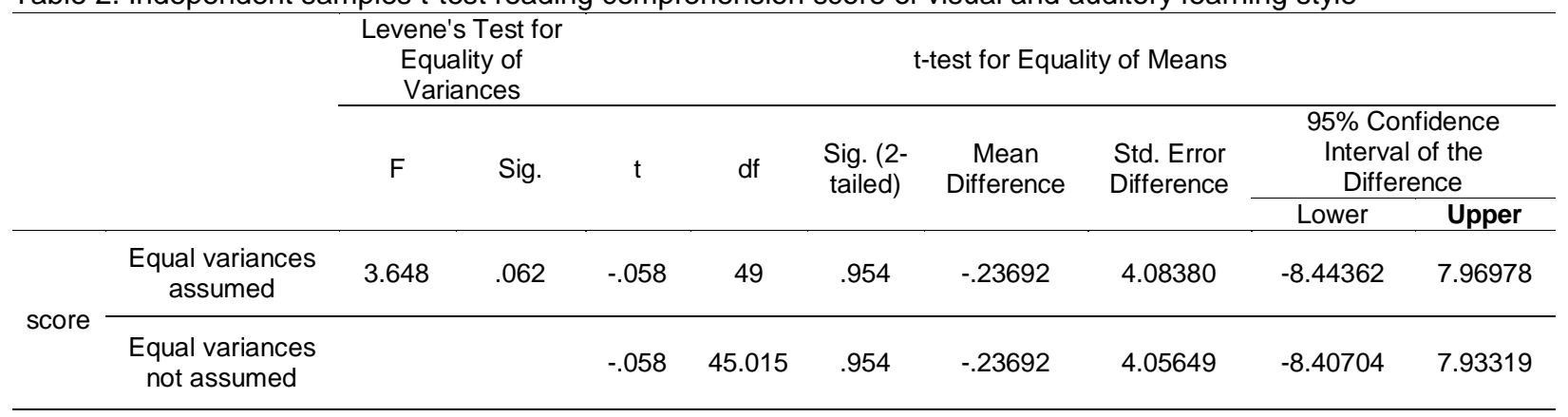


Next, table 3 shows data computation of listening comprehension scores based on visual and auditory leaners. It reveals that the listening score was higher for auditory learning style $(M=58.0, S D=16.11)$ than for visual learning style $(M=57.8, S D=11.8)$. However, after computing independent sample $t$-test based on the output on table 4 , it was found that $t(49)=-0.538, p=$ 0.954 , thus $p>.005$. Considering that the sig. values of two learning style groups (visual and auditory) in Table 3. Group statistics of visual and auditory learning style in listening comprehension score

\begin{tabular}{cccccc}
\hline & Group & N & Mean & $\begin{array}{c}\text { Std. } \\
\text { Deviation }\end{array}$ & $\begin{array}{c}\text { Std. } \\
\text { Error Mean }\end{array}$ \\
\hline \multirow{2}{*}{ score } & $\begin{array}{c}\text { Visual } \\
\text { LS Group }\end{array}$ & 25 & 57.8400 & 11.84511 & 2.36902 \\
\cline { 2 - 5 } & $\begin{array}{c}\text { Auditory } \\
\text { LS Group }\end{array}$ & 26 & 58.0769 & 16.79029 & 3.29285 \\
\hline
\end{tabular}

Table 4. Independent samples test listening comprehension score of visual and auditory learning style

\begin{tabular}{|c|c|c|c|c|c|c|c|c|c|c|}
\hline & & \multicolumn{2}{|c|}{$\begin{array}{l}\text { Levene's Test for } \\
\text { Equality of } \\
\text { Variances }\end{array}$} & \multicolumn{7}{|c|}{ t-test for Equality of Means } \\
\hline & & \multirow[t]{2}{*}{$\mathrm{F}$} & \multirow[t]{2}{*}{ Sig. } & \multirow[t]{2}{*}{$\mathrm{t}$} & \multirow[t]{2}{*}{$\mathrm{df}$} & \multirow[t]{2}{*}{$\begin{array}{l}\text { Sig. (2- } \\
\text { tailed) }\end{array}$} & \multirow[t]{2}{*}{$\begin{array}{c}\text { Mean } \\
\text { Difference }\end{array}$} & \multirow[t]{2}{*}{$\begin{array}{l}\text { Std. Error } \\
\text { Difference }\end{array}$} & \multicolumn{2}{|c|}{$\begin{array}{l}95 \% \text { Confidence } \\
\text { Interval of the } \\
\text { Difference }\end{array}$} \\
\hline & & & & & & & & & Lower & Upper \\
\hline \multirow{2}{*}{ score } & $\begin{array}{l}\text { Equal variances } \\
\text { assumed }\end{array}$ & .583 & .449 & .539 & 49 & .592 & 2.49231 & 4.62134 & -6.79463 & 11.77924 \\
\hline & $\begin{array}{l}\text { Equal variances } \\
\text { not assumed }\end{array}$ & & & .537 & 46.170 & .594 & 2.49231 & 4.64066 & -6.84792 & 11.83254 \\
\hline
\end{tabular}

From table 3 and table 4 , it is clearly shown that there was no significant difference between students' reading and listening comprehension based on their learning styles; visual and auditory. The finding contradicts and refuses the theory and previous research that learning style is influential for achievement (Bhatti and Bart, 2013). Likewise, Rizky's (2013) finding on her research showed that there was significant difference of in students' English achievement based on their visual, auditory, and kinesthetic learning styles. In contrast, the result or finding of this study reveals differently from the previous researcher. The result reported that there was insignificant difference between students' reading and listening comprehension scores based on their learning styles, visual and auditory. It means that contradiction occurred since reading and listening comprehension scores were not affected dominantly by the learning styles (Ellis, 1985). As stated by Ellis (1985) that there are some other factors affecting achievement such as motivation, aptitude, cognitive ability, interest, weather, and others. Thus, it might happen to the reading and listening achievement as well.

Moreover, the insignificant difference between students' reading and listening comprehension scores based on two learning styles, visual and auditory, of the listening comprehension performance were the same, 0.954 , both sig. values were greater than $p$-value $(0.954>0.05)$. Hence, it can be concluded that $\mathrm{HO}$ was accepted and Ha was rejected. Clearly, from the result, it can be said that there was no significant difference in students' listening comprehension based on their learning styles, visual and auditory, as well as in reading comprehension. 
visual learning style tend to understand better when they read the book rather than other kinds of learners. Likewise, auditory learning style is assumed to affect listening comprehension since the auditory learners tend to understand better when they listen to new information rather than read a book. The study investigates the cause and effect between the predictor variables: learning styles and criterion variables; reading and listening comprehension. Causal comparative study is used as research design of the study. Findings of the study showed that $\mathrm{HO}$ was accepted and $\mathrm{Ha}$ was rejected. It means that there was no significant difference between students' learning styles toward their reading and listening comprehension. It reveals that the students' reading and listening comprehension's scores based on their visual and auditory learning style were not significantly different. Hence, it can be concluded that learning styles do not give contribution significantly in affecting reading and listening comprehension scores. In this case, the other factors may give more dominant effect; for instance, cognitive competence. It also means that the students who use their learning style effectively will not necessarily have good achievement in reading and listening, and the students who do not use their REFERENCES

Ary, D., Jacobs, L. C., \& Razavieh, A. (2010). Introduction to research in education, Wardswoth Cengage Learning. Canada: Nelson Education Itd Exotic Classic. (8th Edition ed.). Canada: Nelson Education Itd Exotic Classic.: Wardswoth Cengage Learning.

Barbe, W. B., \& Milone Jr, M. N. . (1981). What we know about modality strengths. Educational Leadership, 38(5), 378-380.

Bhatti, R. U, \& Bart, W. M. (2013). On the effect of learning style on scholastic achievement. Current Issues in Education, 16, 1-7.

Bingol, M. A., Celik, B., Mart, C.T., \& Yilzid, N. (2014). Listening comprehension difficulties encountered by students in second language learning class. Journal of Education and Instructional Studies in the World, 4(4), 1-6.

Braio, A. (1995). Effects of Incrementally introducing learning style strategies on special eduacation and low- achieving general education intermediate students' structural analysis and attitude test scores (Doctoral Dissertation). St. John's University, New York City.

Burnes, D., \& Page, G. (1985). Insight and strategies for teaching reading. New York: Harcourt Brace Jovanich Group. Pty Limited.

Ellis, R. (1985). Second language acquisition. New York: Oxford University Press.

Erginer, E. (2014). A study of the correlation between primary school students' reading comprehension performance and the learning styles based on memory modelling. Education and Science, 39(173), 66-81. learning style effectively will not necessarily have bad achievement in reading and listening.

However, there are several areas that need to be investigated regarding the learners' background and its effect on their reading and listening comprehension, such as individual factors (cognitive competence, motivation, physical factor, and etc.). Regarding that English is a foreign-language in Indonesia, the teachers have to motivate and find a good strategy for the students to practice reading and listening; for instance, encouraging the students to read the books and listen to the information in English as frequently as possible, so that the students can increase their knowledge. Some of the strategies which can be used are having extensive reading, using dictionary, and listening to the English songs, news, and conversations.

The present study is not intentionally dedicated to examine all types of learning styles and their influence on students' reading and listening comprehension, since the focus only on two learning styles: visual and auditory. Therefore, further research is needed since it is still unknown if the kinesthetic learning style will affect reading and listening comprehension of the students.

Gilakjani, A. P. (2012). Visual, auditory, kinaesthetic learning styles and their impact on English language teaching. Journal of Studies in Education, 2(1), 104-113.

Harmer, J. (2001). The practice of English language teaching (Vol. 3rd Edition). New York: Longman.

Moradkhan, D., \& Mirtaheri, S. (2011). The relationship between Iranian EFL learners' perceptual learning styles and their teachers' teaching styles. Journal of English Studies, 1(4), 41-52.

Mueller, D. (1992). An interactive guide to educational research. USA: Allyn and Bacon.

Naning, A. Z., \& Hayati, R. (2011). The correlation between learning style and listening achievement of English Education Study Program students of Sriwijaya University. Jurnal Holistic, 3(5), 1-15.

Osada, N. (2004). Listening comprehension research: A brief review of the past thirty years. Dialogue, 3, 5366.

Pang, E.S., Muaka, A., Bernhardt, E.B., \& Kamil, M.L. (2003). Teaching reading. Switzerland: International Academy for Education.

Purnomo, T. (2009). Students' Learning styles and their efforts to improve speaking skills (A case study at SMA in Bandung) (Unpublished Thesis). Universitas Pendidikan Indonesia, Bandung.

Richard, J.C., \& Platt, J. (1992). Longman dictionary of language teaching and applied linguistics. Harlow: Longman UK Ltd.

Rizky, C. S. (2013). Students' English based on their learning style (A Causal comparative study at second grade students SMP ISLAM Harapan Ibu). (Unpublished Thesis). Universitas Islam Negeri, Jakarta. 
Saadi, I. A. (2012). An examination of the learning styles of saudi preparatory school students who are high or low in reading achievement (Thesis). Victoria University, Australia.

Tanta. (2010). The impact of learning style towards students' study achievement on the subject of general biology, of Biology Education Program. Kreatif Jurnal Kependidikan Dasar, 1(1), 7-20.

Trijono, R. (2015). Metode penelitian kuantitatif. Jakarta: Papas Sinar Sinanti.

Wang, L. (2007). Variation in learning styles in a group of Chinese English as a foreign language learners. International Educational Journal, 8(2), 408-417. 